Aquaculture

February 2015, Volume 437, Pages 201-207

http://dx.doi.org/10.1016/j.aquaculture.2014.11.025

http://archimer.ifremer.fr/doc/00239/35010/

(C) 2014 Elsevier B.V. All rights reserved.

\title{
Assessment of oocyte and trochophore quality in Pacific oyster, Crassostrea gigas
}

\author{
Boulais Myrina ${ }^{1,{ }^{*}}$, Corporeau Charlotte ${ }^{2}$, Huvet Arnaud ${ }^{2}$, Bernard Ismael ${ }^{1}$, Quere Claudie ${ }^{2}$, \\ Quillien Virgile ${ }^{2}$, Fabioux Caroline ${ }^{3}$, Suquet Marc ${ }^{1}$
}

1 Ifremer, LEMAR, UMR 6539, Site Expérimental d'Argenton, 29840 Argenton, France

2 Ifremer, LEMAR, UMR 6539, Technopole Brest Iroise, 29280 Plouzané, France

3 IUEM-UBO, LEMAR, UMR 6539, Technopole Brest Iroise, 29280 Plouzané, France

* Corresponding author : Myrina Boulais, tel.: + 33298892949 ; fax: + 33298895393 ;

email address : myrina.boulais@gmail.com

\begin{abstract}
:
Pacific oyster hatchery production remains highly variable, partially due to inconsistent gamete quality. However, little attention has been paid to oocyte quality in Pacific oyster compared to important vertebrate aquaculture species such as fishes. The aims of the present study were to identify criteria of oocyte and trochophore quality used as predictive tools for embryo developmental success at the Dlarval stage. Twenty-six potential proxies of oocyte and trochophore quality were studied on 25 mature females, as determined using histology. Some morphological and biochemical characteristics of mature oocytes were described. Protein appeared to be the main constituent of fully mature Pacific oyster oocytes. Neutral lipids accounted for $61 \%$ of the total lipids and triglycerides for $85 \%$ of the neutral lipids. Oocyte fertilization capacity was assessed by determining the D-larval yield. High inter-individual variation of D-larval yield was observed (ranging from 1 to $58 \%$ ). D-larval yield was positively correlated with the percentage of motile trochophores $(R 2=0.237)$ and with trochophore Velocity of the Average Path (VAP; R2 $=0.255)$ and negatively correlated with oocyte total steryl esters $(R 2=0.244)$. The use of a multivariate model, including D-larval yield, trochophore VAP and total steryl esters, led to a higher coefficient of determination ( $R 2=0.352$ ), highlighting that the prediction of embryo development in molluscs is a complex process requiring sophisticated multi-factor models.
\end{abstract}




\section{Highlights}

- Twenty six potential proxies of Pacific oyster oocyte and trochophore quality were studied on 25 ripe females. A high inter-individual variation of D-larval yield was observed, ranging from 1 to $58 \%$ - The D-larval yield was correlated with oocyte total steryl ester content, the percentage of motile trochophores and trochophore swimming velocity. Pacific oyster oocyte quality, defined as gamete's potential to produce viable offspring, can be partly predicted using the proxies studied here.

Keywords : Crassostrea gigas, Oocyte quality, Trochophore, Lipid, Gene expression, ATP

\section{Introduction}

Pacific oyster farming traditionally relies on spat collected from the wild. However, the variability of natural spat recruitment from year to year has led to an unpredictable spat supply. Oyster spat production in hatcheries has thus grown up to complement the wild seed supply for the shellfish industry and to respond to demands from farmers for spat reared outside of the natural reproductive season (Robert and Gerard, 1999). The increasing role of oyster hatcheries can therefore be explained by improved control of aquaculture production methods, including breeder selection and the production of special lines, such as triploids (Piferrer et al., 2009). Close to $40 \%$ of spat in France are currently produced by hatcheries but reproductive success is highly variable. This is partially due to the variability of gamete quality (Boudry et al., 2002), defined as a gamete's potential to produce viable offspring which can be quantified by embryo development yields (Kjørsvik et al., 1990). As a consequence, the evaluation and the control of gamete quality are essential to improve aquaculture production of Pacific oyster 
Oocyte quality proxies (i.e., parameters that can be measured in oocytes to predict the development rate of embryos) have been extensively studied in many freshwater and seawater fish species (Bobe and Labbé 2010; Lahnsteiner and Patarnello, 2004). Published studies have mainly focused on oocyte vitelline reserves (lipid, protein, mRNA and vitamin content) required for embryo and larval development. In the rainbow trout, Oncorhynchus mykiss, the levels of some mRNAs have been proposed as egg quality indicators (Aegerter et al, 2005). Although controversial, oocyte size is often used as a quality marker (Baynes et Howell, 1996). Finally, in turbot, Psetta maxima, $\mathrm{pH}$ of ovarian fluid is positively correlated to the fertilization rate (number of fertilized eggs/total number of eggs; Fauvel et al., 1993).

Compared with fish species, only a small panel of criteria is used to assess oocyte quality in bivalves, mainly based on visual observations of different parameters such as oocyte size or shape. Data available on Pacific oyster have shown that the oocyte is constituted of 44 - 74\% protein, 16 - 38\% lipid and 7 - 12\% carbohydrate (Massapina et al., 1999). Mature Pacific oyster oocytes were found to have a mean diameter of $36.1 \pm 4.4 \mu \mathrm{m}$ (Lango-Reynoso et al., 2000). The biochemical content of oocytes was used to evaluate gamete quality, revealing a significant relationship between oocyte organic matter or total lipid contents and D-larval yield (Massapina et al., 1999). However, this work was carried out on oysters with a particular spawning pattern: a long spawning period (five months), including two spawning peaks and partial spawning.

The objectives of the present work were to identify criteria of oocyte and trochophore quality in order to use them as predictive tools for embryo developmental success at the Dlarval stage. We described some morphological and biochemical characteristics of Pacific oyster mature oocytes, we determined $\mathrm{pH}$ of female oyster gonad because potentially related to oocyte characteristics and we described some larval biological features (trochophore motility, D-larval morphology). In addition, we individually correlated these parameters to 
oocyte fertilization capacity to identify which ones could be related to oocyte and trochophore quality.

\section{Materials and methods}

\subsection{Oyster conditioning and selection of females}

Two batches of three-year-old Pacific oysters were collected from Aber Benoît estuary (North Brittany, France) on 7 December 2009 (conditioning 1) and on 22 February 2010 (conditioning 2). Oysters were transferred to the experimental hatchery of Ifremer (Argenton, France) and conditioned (conditioning 1: 10 weeks, conditioning 2: 8 weeks) using conditions suitable for germ cell maturation according to Fabioux et al. (2005).

At the end of the conditioning period, oyster sex was determined by examination of 2 $\mu 1$ gonad samples under a light microscope (Leica MZ 125, $\times 4$ objective). A 2-3 mm cross section of the visceral mass was excised in front of the pericardic region and prepared for histology (Fabioux et al., 2005). Since our study aimed at describing the main biological characteristics of mature Pacific oyster oocytes, only stage-3 females (with ripe oocytes, as described in Steele and Mulcahy, 1999) of each conditioning were selected on the basis of histological description $(n=25)$.

\subsection{Gonad $\mathrm{pH}$}

Gonadic $\mathrm{pH}$ was determined by inserting a pipette into the gonad and withdrawing a sample (volume<50 $\mu \mathrm{l}$ ) which was transferred to a microelectrode (IQ Scientific Instruments). 


\subsection{Oocyte sampling and measurements}

\subsubsection{Oocyte morphological measurements}

For oocyte morphological measurements, a $50 \mu \mathrm{l}$ gonad sample was collected and deposited in a well of a 24-well microplate $\left(\mathrm{Nunc}^{\mathrm{TM}}\right)$, which was filled up with $19^{\circ} \mathrm{C}$ seawater that had been filtered at $1 \mu \mathrm{m}(\mathrm{FSW})$. One minute after collection, oocyte pictures were taken using a camera (SONY 3 CCD Color Video Camera) connected to a microscope (Leica, DMIL, 10x objective). Oocyte circularity (ranging from 0 to 1 , where a value of 1 indicates a perfect circle) and maximal diameter were measured using Image $\mathbf{J}$ software $(n=30$ oocytes for each female).

\subsubsection{Oocyte biochemical measurements}

The oyster gonads were then stripped individually using $5 \mathrm{ml}$ FSW. The oocyte suspension was filtered $(100 \mu \mathrm{m})$, transferred to $2 \mathrm{~L}$ containers filled with FSW and oocyte number was determined in triplicate as previously described in Song et al. (2009).

For the quantification of neutral lipid content, $5 \times 10^{5}$ oocytes were transferred to a $100 \mathrm{ml}$ container and filtered (Whatman ${ }^{\circledR}, 47 \mathrm{~mm}$ ). The filter was then stored at $-20^{\circ} \mathrm{C}$, in 6 ml Folch (chloroforme/methanol: 2V/1V). The neutral lipid classes of oocytes were assessed according to Ben Kheder et al. (2010).

To assess oocyte ATP (adenosine triphosphate) content, $10^{4}$ oocytes were transferred into a $5 \mathrm{ml}$ cryotube (Nunc ${ }^{\mathrm{TM}}$ ) and stored in liquid nitrogen until further analysis. Oocyte ATP content was then determined using the Luminescence ATP Detection Assay System kit (Perkin Elmer, EnSpireTM 2300 Multilabel Reader), according to Suquet et al. (2010).

For the quantification of oocyte protein content, $2 \times 10^{6}$ oocytes were sampled, placed in a $50 \mathrm{ml}$ Falcon tube and collected through centrifugation at $1000 \mathrm{rpm}$ for 2 minutes at $4{ }^{\circ} \mathrm{C}$ 
(Corporeau et al., 2012). The supernatant was then removed and $5 \mathrm{ml}$ of lysis buffer $(150 \mathrm{mM}$ $\mathrm{NaCl}, 10 \mathrm{mM}$ Tris, $1 \mathrm{mM}$ EDTA, $1 \mathrm{mM}$ EGTA, $1 \%$ Triton $\mathrm{X}-100,0.5 \%$ Igepal, 1 tablet of complete EDTA free protease inhibitor cocktail/25 ml buffer) was added to solubilise the proteins. Samples were frozen and stored at $-80^{\circ} \mathrm{C}$. Proteins were then extracted as described by Guevelou et al. (2013). Total protein content was quantified using a $\mathrm{D}_{\mathrm{C}}$ protein assay (BioRad, Hercules, CA, USA) with a 96-well microplate $\left(\mathrm{Nunc}^{\mathrm{TM}}\right)$ in a micro-plate reader (BioTek $^{\circledR}$ Synergy ${ }^{\mathrm{TM}} \mathrm{HT}$ ) connected to KC4 v3 software.

For gene expression analysis, total RNA was extracted from $2 \times 10^{4}$ oocytes from each

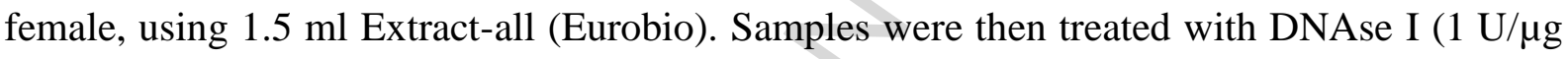
total RNA, Sigma). RNA quality was assessed using RNA nano chips and Agilent RNA 6000 nano reagents (Agilent Technologies, Waldbronn, Germany) and RNA concentrations were measured using an ND-1000 spectrophotometer (Nanodrop Technologies). From $2 \mu \mathrm{g}$ of total RNA, reverse transcription and real-time PCR amplifications were carried out for $10 \mathrm{mRNA}$ genes as described in Huvet et al. (2004). PCR efficiency (E) was estimated for each primer pair by determining the slopes of standard curves obtained from serial dilution analysis of a cDNA sample. Primer names, accession numbers, PCR efficiencies and sequences are listed in Table 1. In the present study, amplification of elongation factor I (Efl $\alpha)$ cDNA (primers in Fabioux et al., 2004) was performed to provide an internal control for gene expression. Overall the samples, the coefficient of variation of quantification cycle $(\mathrm{Cq})$ values for $E f 1 \alpha$ was very low, at $2.70 \%$. For a studied gene “i”, results were expressed as $2^{-\Delta \Delta \mathrm{Cq}}$ (Pfaffl, 2001) with $\Delta \mathrm{Cq}=\mathrm{Cq}(\mathrm{i})-\mathrm{Cq}(E f 1 \alpha)$ and $\Delta \Delta \mathrm{Cq}=\Delta \mathrm{Cq}$ of cDNA sample $-\Delta \mathrm{Cq}$ of a cDNA reference.

\subsection{Larval biological measurements and oocyte fertilization capacity}




\subsubsection{Oocyte fertilization}

Oocytes were fertilized using a pool of sperm collected from three males: testes were individually stripped in $10 \mathrm{ml}$ "Store Gigas" (a salt sperm immobilising solution; Brizard et al., 2008). The sperm suspension was then filtered at $60 \mu \mathrm{m}$ to remove any large pieces of gonad material, and stored at $4^{\circ} \mathrm{C}$ until fertilization. Sperm concentration was assessed by Coulter Counter (duplicates) after dilution in FSW (dilution rate 1:1000). Fertilization procedure was as follows: for each female, triplicate beakers of 25000 oocytes were fertilized in $50 \mathrm{ml} \mathrm{FSW}$, using a non limiting sperm to oocyte ratio (400:1). After 30 minutes of contact between spermatozoa and oocytes, beakers were filled up to 1.8 litres with FSW for incubation.

\subsubsection{Motility features of trochophore larvae}

Trochophore movement characteristics were recorded $24 \mathrm{~h}$ post fertilization at $19^{\circ} \mathrm{C}$ : for each beaker 30 trochophores were collected and placed on a glass slide. The percentage of motile trochophores (motility) and trochophore Velocity of the Average Path (VAP) were recorded using a dissecting microscope (Leica, MZ125, 4x objective) connected to a camera (SONY Exwave HAD) and assessed using a CASA (Computer Assisted Sperm Analyser) plug-in developed for the Image J software (Wilson-Leedy and Ingermann, 2007) with previously defined calibration settings (Suquet et al., 2012).

\subsubsection{Oocyte fertilization capacity}

Oocyte fertilization capacity was assessed by determining the D-larval yield, $48 \mathrm{~h}$ post fertilization. The D-larval yield (\%) was estimated $48 \mathrm{~h}$ post fertilization and corresponds to the number of D-larvae/total number of oocytes used for fertilization. For each beaker, larvae were concentrated in a $10 \mathrm{~mL}$ graduated cylinder using a $20 \mu \mathrm{m}$ mesh and larvae number was 
determined by microscopic count $(3 \times 50 \mu 1)$. Non-viable larvae (translucent or non D-shaped) were not counted.

\subsubsection{D-larval morphological measurements}

In order to describe D-larval morphology, concentrated larvae were transferred in a well of a 24-well micro-plate ( $\mathrm{Nunc}^{\mathrm{TM}}$ ) filled with FSW. Maximal diameter and circularity of 30 D-larvae were analysed as described previously for oocyte morphological criteria.

\subsection{Statistical analysis}

Results were presented as mean \pm SEM. D-larval yields were arcsin square-root transformed and mean were compared using a one-way ANOVA. When significant differences were observed, a Fisher a posteriori test was used. Simple correlations between the different characteristics measured at oocyte, trochophore or D-larval stages were tested using linear regressions. Multiple correlations between oocyte or trochophore characteristics and D-larval yield were then analysed. A value of $\mathrm{p}<0.05$ was considered as the threshold of significance. The coefficient of determination $\left(\mathrm{R}^{2}\right)$ was used to quantify the linear relationship between variables for simple correlations and the adjusted $\mathrm{R}^{2}$ for multivariate correlations.

\section{Results}

On the basis of histological description, 25 stage-3 females were selected: respectively, 15 and 10 females from the conditioning 1 and 2 .

The mean values of the 26 variables describing gonad, oocyte, trochophore and larval characteristics are shown in Table 2. Gonad $\mathrm{pH}$ was rather acidic, with individual values ranging from 5.9 to 6.7 . Biochemical analysis showed that proteins were the main constituent 
of fully mature Pacific oyster oocyte. Among oocyte lipid content, neutral lipids accounted for $61 \%$ of the total lipids and triglycerides for $85 \%$ of the neutral lipids. A high individual variation (coefficient of variation>100\%) was observed for three mRNA levels: Irp, Vtg1 and $\operatorname{Vtg} 2$.

Movement was recorded in $72 \%$ of the trochophores at $24 \mathrm{~h}$ post fertilization. A significant variation in D-larval yield was observed between females $(\mathrm{p}=0.0001$, range: 1 $58 \%$, Fig. 1) with an overall mean D-larval yield of $31.8 \%$. A D-larval yield lower than $20 \%$ was measured for six females and a value higher than $50 \%$ for four females.

Significant linear regressions were found between oocyte, trochophore and larval characteristics. Out of the ten genes assayed for mRNA levels, only the insulin relative receptor (CIR) showed a significant correlation with other phenotypes described in oocytes: the CIR mRNA level was negatively correlated with the oocyte ATP content $\left(p=0.0004 ; R^{2}\right.$ $=0.431$; Fig.2a). The percentage of motile trochophores was positively correlated with trochophore VAP $\left(\mathrm{p}=0.0001 ; \mathrm{R}^{2}=0.518 ;\right.$ Fig.2b). Furthermore, the D-larval yield was positively correlated with the percentage of motile trochophores $\left(p=0.014 ; R^{2}=0.237\right.$; Fig.2c) and with trochophore VAP $\left(p=0.010 ; R^{2}=0.255 ;\right.$ Fig. $\left.2 d\right)$ and negatively correlated with total steryl esters $\left(p=0.012 ; R^{2}=0.244\right.$; Fig.2e). A significant multivariate correlation was noted between D-larval yield and both trochophore VAP and total steryl esters as independent variables $\left(\mathrm{p}=0.0032 ; \mathrm{R}^{2}=0.352\right)$.

\section{Discussion}

The present study determined $\mathrm{pH}$ of the female gonad, several morphological and biochemical characteristics of Pacific oyster mature oocytes and some larval biological features (trochophore motility and D-larval morphology), thus expanding the limited 
knowledge previously available in the scientific literature. Mature Pacific oyster gonad was found to be acidic ( $\mathrm{pH}$ 6.25), a characteristic suggested to prevent germinal vesicle breakdown (GVBD) at $\mathrm{pH}$ below 6.5 (Osanai, 1985). In contrast to the results reported in turbot (Fauvel et al., 1993), no correlation was observed between gonadic pH and D-larval yield in Pacific oyster. Oocyte maximal diameter determined in this work was in the same range as values reported by Burlot et al. (1998) for mature oocytes (from 60 to $70 \mu \mathrm{m}$ ).

Several biochemical features of Pacific oyster oocytes were described in this study. To our knowledge, this is the first time that oocyte ATP content has been reported in a mollusc species. Fish eggs show ATP contents 7000 to 30000 times higher than the mean value observed in Pacific oyster $\left(0.24 \pm 0.01\right.$ pmol.oocyte $\left.{ }^{-1}\right): 1.66 \pm 0.01$ nmol.egg ${ }^{-1}$ in rainbow trout (Wendling et al., 2004) up to $7.76 \pm 6.20 \mathrm{nmol.egg}^{-1}$ in gilthead seabream (Sparus aurata; Lahnsteiner and Patarnello, 2004). However, the biological significance of such comparison is difficult to interpret because fish eggs are 10 to 50 times larger than Pacific oyster oocytes and because the number of mitochondria may differ greatly.

Oocyte mean protein and lipid contents assessed in the present work are consistent with the values reported by Massapina et al. (1999) for Pacific oyster oocytes. Proteins and lipids are accumulated during Pacific oyster oogenesis (Li et al., 2000) and are essential for embryogenesis and early development as they provide nutrient reserves for larvae which are autotrophic until the D-larval stage. In Pacific oyster (present work), but also in Eastern oyster (Crassostrea virginica; Thompson et al., 1996), protein has been found to be the predominant constituent of oocytes. Maternally provided proteins are degraded early in development, activating the embryonic developmental programs (Li et al., 2010). The support of embryo development by proteolysis has been demonstrated in different marine fish species (Ronnestad et al., 1998). Lipids have important roles in energy metabolism during oocyte maturation (Sturmey et al., 2009) and previous studies have highlighted their importance in 
bivalve oocyte (Gómez-Roblez et al., 2005). During oogenesis, oocytes acquire their lipid reserves directly from the animal's food intake. Neutral lipids are generally considered as the most important energy reserve in marine fish eggs (Vetter et al., 1983). Triglycerides accounted for $52 \%$ of the total lipids in the present study, confirming they are the main lipid reserve of bivalve oocytes as in the giant scallop (Placopecten magellanicus) oocyte, where they account for $60 \%$ of the total lipids (Napolitano et al., 1992) and in the Eastern oyster oocyte where they account for $76 \%$ (Lee and Heffernan, 1991). The main triglyceride source for bivalve oocytes is the glycogen stored in the gonad during gametogenesis (Barber and Blake, 1985) and the triglyceride content of the gonad has been seen to faithfully reflect the course of sexual maturation in Pacific oyster (Osada et al., 2000). Triglycerides are considered as the main class of lipids catabolized during embryogenesis in the Eastern oyster and are crucial for larval survival and successful metamorphosis (Gallager and Mann, 1986) because their saturated fatty acids represent a source of energy and because they may also serve as temporary reservoir of polyunsaturated fatty acid (Napolitano et al., 1988).

No positive correlation was found between D-larval yield and oocyte lipid content in the present work. In contrast, survival to the D-larval stage has previously been found to be correlated with the oocyte total lipid content in Pacific oyster (Massapina et al., 1999) and in scallop (Pecten maximus; Dorange et al., 1989), confirming that the lipids stored in the oocyte during gametogenesis play a major role as an energy source for embryonic and early larval development. The lack of positive correlations between neutral lipid content and larval development suggests that sufficient lipid reserves were stored in the oocyte during the oyster conditioning period and that there exists a threshold of oocyte lipid levels, below which optimal embryonic and larval development are impeded, as already suggested in hard clam (Mercenaria mercenaria) and Eastern oyster (Gallager and Mann, 1986). Surprisingly, the total steryl ester content of oocytes was negatively correlated with D-larval yield. However, 
Soudant et al. (1996) also obtained a better hatching rate in the scallop when proportions of oocyte total steryl esters were low. Steryl esters are stored in the developing oocyte, mostly in the form of cholesterol, and then used by the embryo for biosynthesis of the plasma membrane, controlling membrane fluidity and permeability (Simons and Vaz, 2004). Berenberg and Patterson (1981) observed that the Eastern oyster synthesized, transformed or preferentially incorporated cholesterol when this was present at low levels in the diet. Further analysis of sterol components in the total steryl ester fraction would be of interest to better understand the negative impact of a high total steryl ester content on oocyte quality.

The mRNA levels of ten genes, including some maternal mRNAs, were estimated here in Pacific oyster oocyte. These ten candidates were selected for their annotations in the literature and because they were already reported to correlate with oocyte quality in vertebrate species such as fishes (e.g. Aegerter et al., 2004; 2005). Surprisingly, only the insulin relative receptor correlated negatively with the oocyte ATP content here. On the contrary, no clear link was established between the insulin pathway and ATP in lamb oocytes when supplemented with insulin (Catala et al., 2013). Further analysis of gene expression using high-throughput technologies (e.g. oligoarray, RNAseq, etc...) will be of interest to assess molecular markers of oyster oocyte quality.

The mean values of trochophore swimming characteristics, assessed $24 \mathrm{~h}$ post fertilization, are close to those previously reported for the same species (percentage of swimming trochophores: $85 \pm 10 \%$, VAP: $146 \pm 75 \mu \mathrm{ms}^{-1}$; Suquet et al., 2013). Similar swimming speeds were reported for Eastern oyster trochophores (100 to $300 \mu \mathrm{ms}^{-1}$; Hidu and Haskin, 1978). We demonstrated a significant correlation between the percentage of motile trochophores and their swimming speed. Both trochophore movement characteristics may be suggested to depend on embryo integrity which results from normal embryonic development. Trochophore movement characteristics may also depend on the embryo energy content 
available for movement. However, we found no correlation between ATP content of oocyte and trochophore movement features in our work, suggesting that such movement relies on a trochophore's own capacity to produce energy. ATP requirement for normal development of mollusc embryo remains to be investigated.

The percentage of motile trochophores and their VAP were positively correlated with Pacific oyster larval development. Changes in trochophore VAP were considered to be a reliable estimation of the quality of thawed oyster larvae (Suquet et al., 2012). Since trochophore VAP was obtained $24 \mathrm{~h}$ after fertilization $\left(\mathrm{T}=19^{\circ} \mathrm{C}\right)$, it could be considered as a late predictive parameter of oocyte quality.

In the present study, the use of a multivariate model, including D-larval yield, trochophore VAP and total steryl esters, led to a better coefficient of determination $\left(\mathrm{R}^{2}=\right.$ 0.352). However, the predictive efficiency of this correlation remains limited. According to Lubzens et al. (2010), egg quality is determined by a multi factor process, with biochemical, genetic and physiological components, as also suggested for fish eggs (Bobbe and Labbé, 2010). Predicting embryo development in molluscs as in fish is a complex process requiring sophisticated multi-factor models.

We suggest the integration of additional parameters to improve oocyte quality evaluation. Such parameters could include further analyses of gene expression and of protein composition of oocytes. A recent study in Pacific oyster showed that differentially accumulated proteins in oocytes are linked to their quality (Corporeau et al., 2012). A specific expression of proteins, such as Nme related proteins, may help to separate oocytes of different quality, as reported for seabass (Dicentrarchus labrax) eggs (Crespel et al., 2008). Furthermore, oocyte lipid composition, and more specifically sterol components in the total steryl ester fraction, could be explored. Then, considering the complexity of the processes 
defining oocyte quality, it would be useful to adapt other technologies to bivalve oocyte, such as flow cytometric protocols to assess cellular parameters (Le Goïc et al., 2015).

In conclusion, the present study provides a better knowledge of the biological characteristics of mature Pacific oyster oocytes. The studied oocyte characteristics were partly predictive of successful embryo development, highlighting the complexity of predicting embryo development in molluscs, as already suggested in vertebrates. However, we demonstrated that oocyte quality can be partly determined at the trochophore stage.

\section{Acknowledgments}

The authors wish to thank I. Quéau, L. Lebrun and C. Mingant for rearing the algae and oysters in the facilities at Ifremer. We acknowledge P. Soudant (UBO/IUEM) for fruitful discussions and J.L. Nicolas for his help. This work was supported by the European project Reproseed (FP7-KBE-2009-3). M. Boulais was funded by Ifremer and by a doctoral grant from Région Bretagne.

\section{Figure captions}

Fig.1. Individual D-larval yields of Pacific oysters ( $n=25$ females).

Fig.2. Correlations observed between the different oocyte characteristics or between D-larval yield and oocyte or trochophore characteristics $(n=25$ females for all parameters except $2 \mathrm{~A}$ : where $n=22$ ).

\section{References}


Aegerter, S., Jalabert, B., Bobe, J., 2004. Messenger RNA stockpile of cyclin B, insulin-like growth factor I, insulin-like growth factor II, insulin-like growth factor receptor Ib, and p53 in the rainbow trout oocyte in relation with developmental competence. Mol. Reprod. Dev. 67, 127-135. doi:10.1002/mrd.10384

Aegerter, S., Jalabert, B., Bobe, J., 2005. Large scale real-time PCR analysis of mRNA abundance in rainbow trout eggs in relationship with egg quality and post-ovulatory ageing. Mol. Reprod. Dev. 72, 377-385. doi:10.1002/mrd.20361

Barber, B., Blake, N., 1985. Intra-organ biochemical transformations associated with oogenesis in the bay scallop, Argopecten,irradians concentricus (Say), as indicated by C-14 incorporation. Biol. Bull. 168, 39-49. doi:10.2307/1541172

Baynes, S., Howell, B., 1996. The influence of egg size and incubation temperature on the condition of Solea solea (L) larvae at hatching and first feeding. J. Exp. Mar. Biol. Ecol. 199, 59-77. doi:10.1016/0022-0981(95)00189-1

Ben Kheder, R., Quere, C., Moal, J., Robert, R., 2010. Effect of nutrition on Crassostrea gigas larval development and the evolution of physiological indices. Part A: Quantitative and qualitative diet effects. Aquaculture 305, 165-173. doi:10.1016/j.aquaculture.2010.04.022

Berenberg, C., Patterson, G., 1981. The relationship between dietary phytosterols and the sterols of wild and cultivated oysters. Lipids 16, 276-278. doi:10.1007/BF02535028

Bobe, J., Labbe, C., 2010. Egg and sperm quality in fish. Gen. Comp. Endocrinol. 165, 535548. doi:10.1016/j.ygcen.2009.02.011

Boudry, P., Collet, B., Cornette, F., Hervouet, V., Bonhomme, F., 2002. High variance in reproductive success of the Pacific oyster (Crassostrea gigas, Thunberg) revealed by microsatellite-based parentage analysis of multifactorial crosses. Aquaculture 204, 283-296. doi:10.1016/S0044-8486(01)00841-9

Brizard, R., Bernardi, M., Boudry, P., Haffray, P., Labbé, C., Maisse, G., Maurouard, E., Robert, R., Roger, J.L., 2001. Bilan du projet Cryoyster, Ifremer, 36pp.

Catala, M.G., Roura, M., Izquierdo, D., Morato, R., Hammami, S., Paramio, M.T., 2013. Blastocyst development, MPF activity and ATP content of lamb oocytes supplemented with insulin-transferrin-selenium (ITS) and ascorbic acid at IVM. Small Rumin. Res. 112, 103-107. doi:10.1016/j.smallrumres.2012.12.007

Corporeau, C., Vanderplancke, G., Boulais, M., Suquet, M., Quere, C., Boudry, P., Huvet, A., Madec, S., 2012. Proteomic identification of quality factors for oocytes in the Pacific oyster Crassostrea gigas. J. Proteomics 75, 5554-5563. doi:10.1016/j.jprot.2012.07.040

Crespel, A., Rime, H., Fraboulet, E., Bobe, J., Fauvel, C., 2008. Egg quality in domesticated and wild seabass (Dicentrarchus labrax): A proteomic analysis. Cybium 32, 205.

Dorange, G., Paulet, Y., Le pennec, M., Cochard, J., 1989. Criteria for quality assessment of spawned oocytes of Pecten maximus (Mollusca, Bivalvia). Comptes rendus Acad. Sci. Ser. III-Sci. Vie-Life Sci. 309, 113-120.

Fabioux, C., Huvet, A., Le Souchu, P., Le Pennec, M., Pouvreau, S., 2005. Temperature and photoperiod drive Crassostrea gigas reproductive internal clock. Aquaculture 250, 458-470. doi:10.1016/j.aquaculture.2005.02.038

Fabioux, C., Huvet, A., Lelong, C., Robert, R., Pouvreau, S., Daniel, J., Minguant, C., Le Pennec, M., 2004. Oyster vasa-like gene as a marker of the germline cell development in Crassostrea gigas. Biochem. Biophys. Res. Commun. 320, 592-598. doi:10.1016/j.bbrc.2004.06.009

Fauvel, C., Omnès, M.H., Suquet, M., Normant, Y., 1993. Reliable assessment of overripening in turbot (Scophthalmus maximus) by a simple $\mathrm{pH}$ measurement. Aquaculture 117, 107-113. doi: 10.1016/0044-8486(93)90127-K 
Gallager, S., Mann, R., 1986. Growth and survival of larvae of Mercenaria mercenaria (L) and Crassostrea virginica (Gmelin) relative to broodstock conditioning and lipid content of eggs. Aquaculture 56, 105-121. doi:10.1016/0044-8486(86)90021-9

Gómez-Robles, E., Rodriguez-Jaramillo, C., Saucedo, P., 2005. Digital image analysis of lipid and protein histochemical markers for measuring oocyte development and quality in pearl oyster Pinctada mazatlanica (Hanley, 1856). J. Shellfish Res. 24, 1197-1202.

Guevelou, E., Huvet, A., Sussarellu, R., Milan, M., Guo, X., Li, L., Zhang, G., Quillien, V., Daniel, J.-Y., Quere, C., Boudry, P., Corporeau, C., 2013. Regulation of a truncated isoform of AMP-activated protein kinase alpha (AMPK alpha) in response to hypoxia in the muscle of Pacific oyster Crassostrea gigas. J. Comp. Physiol. B-Biochem. Syst. Environ. Physiol. 183, 597-611. doi:10.1007/s00360-013-0743-6

Hidu, H., Haskin, H., 1978. Swimming speeds of oyster larvae Crassostrea virginica in different salinities and temperatures. Estuaries 1, 252-255. doi:10.2307/1351527

Huvet, A., Herpin, A., Degremont, L., Labreuche, Y., Samain, J., Cunningham, C., 2004. The identification of genes from the oyster Crassostrea gigas that are differentially expressed in progeny exhibiting opposed susceptibility to summer mortality. GENE 343, 211-220. doi:10.1016/j.gene.2004.09.008

Kjørsvik, E., Mangorjensen, A., Holmefjord, I., 1990. Egg quality in fishes. Adv. Mar. Biol. 26, 71-113. doi:10.1016/S0065-2881(08)60199-6

Lahnsteiner, F., Patarnello, P., 2004. Egg quality determination in the gilthead seabream, Sparus aurata, with biochemical parameters. Aquaculture 237, 443-459. doi:10.1016/j.aquaculture.2004.04.017

Lango-Reynoso, F., Chavez-Villalba, J., Cochard, J., Le Pennec, M., 2000. Oocyte size, a means to evaluate the gametogenic development of the Pacific oyster, Crassostrea gigas (Thunberg). Aquaculture 190, 183-199. doi:10.1016/S0044-8486(00)00392-6

Lee, R., Heffernan, P., 1991. Lipids and proteins in eggs of Eastern oysters (Crassostrea Virginica; Gmelin, 1971) and Northern quahogs (Mercenaria mercenaria; Linnaeus, 1758). J. Shellfish Res. 11, 203-205.

Le Goïc, N., Hégaret, H., Boulais, M., Béguel, J.P., Lambert, C., Fabioux, C., Soudant, P., 2015. Flow cytometric assessment of assess morphology, viability and production of reactive oxygen species of Crassostrea gigas oocytes. Application to Toxic dinoflagellate (Alexandrium minutum) exposure. Cytometry Part A, In Press. doi: 10.1002/cyto.a.22577

Li, Q., Osada, M., Mori, K., 2000. Seasonal biochemical variations in Pacific oyster gonadal tissue during sexual maturation. Fish. Sci. 66, 502-508.

Li, L., Zheng, P., Dean, J., 2010. Maternal control of early mouse development. Development 137, 859-870. doi:10.1242/dev.039487

Lubzens, E., Young, G., Bobe, J., Cerda, J., 2010. Oogenesis in teleosts: How fish eggs are formed. Gen. Comp. Endocrinol. 165, 367-389. doi:10.1016/j.ygcen.2009.05.022

Massapina, C., Joaquim, S., Matias, D., Devauchelle, N., 1999. Oocyte and embryo quality in Crassostrea gigas (Portuguese strain) during a spawning period in Algarve, South Portugal. Aquat. Living Resour. 12, 327-333. doi:10.1016/S0990-7440(99)00115-1

Napolitano, G., Macdonald, B., Thompson, R., Ackman, R., 1992. Lipid composition of eggs and adductor muscle in giant scallops (Placopecten magellanicus) from different habitats. Mar. Biol. 113, 71-76. doi:10.1007/BF00367640

Napolitano, G., Ratnayake, W., Ackman, R., 1988. Fatty acid components of larval ostrea edulis (L) - Importance of triacylglycerols as a fatty acid reserve. Comp. Biochem. Physiol. B-Biochem. Mol. Biol. 90, 875-883. doi:10.1016/0305-0491(88)90348-3

Osanai, K., 1985. In vitro induction of germinal vesicle breakdown in oyster oocytes. Bull. Mar. Biol. Stn. Asamushi, Tohoku University 18, 1-9. 
Pfaffl, M.W., 2001. A new mathematical model for relative quantification in real-time RTPCR. Nucleic Acids Res. 29, 2002-2007.

Piferrer, F., Beaumont, A., Falguiere, J.-C., Flajshans, M., Haffray, P., Colombo, L., 2009. Polyploid fish and shellfish: Production, biology and applications to aquaculture for performance improvement and genetic containment. Aquaculture 293, 125-156. doi:10.1016/j.aquaculture.2009.04.036

Robert, R., Gérard, A., 1999. Bivalve hatchery technology: The current situation for the Pacific oyster Crassostrea gigas and the scallop Pecten maximus in France. Aquat. Living Resour. 12, 121-130. doi:10.1016/S0990-7440(99)80021-7

Ronnestad, I., Koven, W., Tandler, A., Harel, M., Fyhn, H., 1998. Utilisation of yolk fuels in developing eggs and larvae of European sea bass (Dicentrarchus labrax). Aquaculture 162, 157-170. doi:10.1016/S0044-8486(98)00203-8

Simons, K., Vaz, W., 2004. Model systems, lipid rafts, and cell membranes. Annu. Rev. Biophys. Biomol. Struct. 33, 269-295. doi:10.1146/annurev.biophys.32.110601.141803

Song, Y.P., Suquet, M., Queau, I., Lebrun, L., 2009. Setting of a procedure for experimental fertilisation of Pacific oyster (Crassostrea gigas) oocytes. Aquaculture 287, 311-314. doi:10.1016/j.aquaculture.2008.10.018

Soudant, P., Marty, Y., Moal, J., Robert, R., Quere, C., LeCoz, J., Samain, J., 1996. Effect of food fatty acid and sterol quality on Pecten maximus gonad composition and reproduction process. Aquaculture 143, 361-378. doi:10.1016/0044-8486(96)01276-8

Steele, S., Mulcahy, M., 1999. Gametogenesis of the oyster Crassostrea gigas in southern Ireland. J. Mar. Biol. Assoc. U. K. 79, 673-686. doi:10.1017/S0025315498000836

Sturmey, R.G., Reis, A., Leese, H.J., McEvoy, T.G., 2009. Role of Fatty Acids in Energy Provision During Oocyte Maturation and Early Embryo Development. Reprod. Domest. Anim. 44, 50-58. doi:10.1111/j.1439-0531.2009.01402.x

Suquet, M., Labbe, C., Brizard, R., Donval, A., Le Coz, J.R., Quere, C., Haffray, P., 2010. Changes in motility, ATP content, morphology and fertilisation capacity during the movement phase of tetraploid Pacific oyster (Crassostrea gigas) sperm. Theriogenology 74, 111-117. doi:10.1016/j.theriogenology.2010.01.021

Suquet, M., Le Mercier, A., Rimond, F., Mingant, C., Haffray, P., Labbe, C., 2012. Setting tools for the early assessment of the quality of thawed Pacific oyster (Crassostrea gigas) D-larvae. Theriogenology 78, 462-467. doi:10.1016/j.theriogenology.2012.02.014

Suquet, M., Quere, C., Mingant, C., Lebrun, L., Ratiskol, D., Miner, P., Cosson, J., 2013. Effect of sampling location, release technique and time after activation on the movement characteristics of scallop (Pecten maximus) sperm. Aquat. Living Resour. 26, 215-220. doi:10.1051/alr/2013048

Thompson, R.J., Newell, R.I.E., Kennedy, V.S., Mann, R., 1996. Reproductive processes and early development. In: Kennedy, V.S., Newell, R.I.E., Eble, A.F. (Eds.), The Eastern oyster, Crassostrea virginica, Maryland Sea Grant College, Maryland, pp.335-370.

Vetter, R.D., Hodson, R.E., Arnold, C., 1983. Energy Metabolism in a Rapidly Developing Marine Fish Egg, the Red Drum (Sciaenops ocellata). Can. J. Fish. Aquat. Sci. 40, 627-634.

Wendling, N., Bencic, D., Nagler, J., Cloud, J., Ingermann, R., 2004. Adenosine triphosphate levels in steelhead (Oncorhynchus mykiss) eggs: an examination of turnover, localization and role. Comp. Biochem. Physiol. -Mol. Integr. Physiol. 137, 739-748. doi:10.1016/j.cbpb.2004.02.009 
Wilson-Leedy, J.G., Ingermann, R.L., 2007. Development of a novel CASA system based on open source software for characterization of zebrafish sperm motility parameters. Theriogenology 67, 661-672. doi:10.1016/j.theriogenology.2006.10.003 


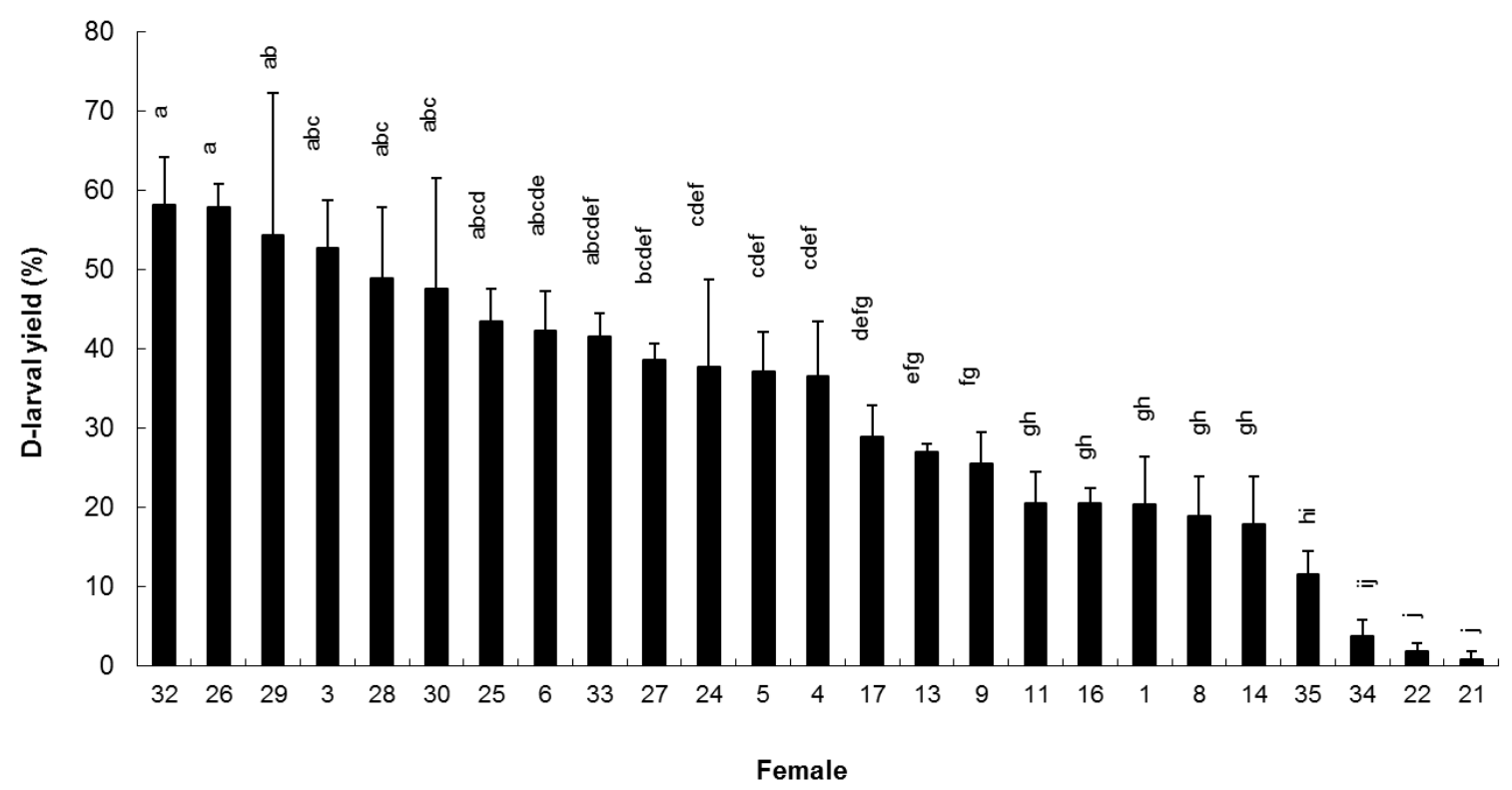

Figure 1 

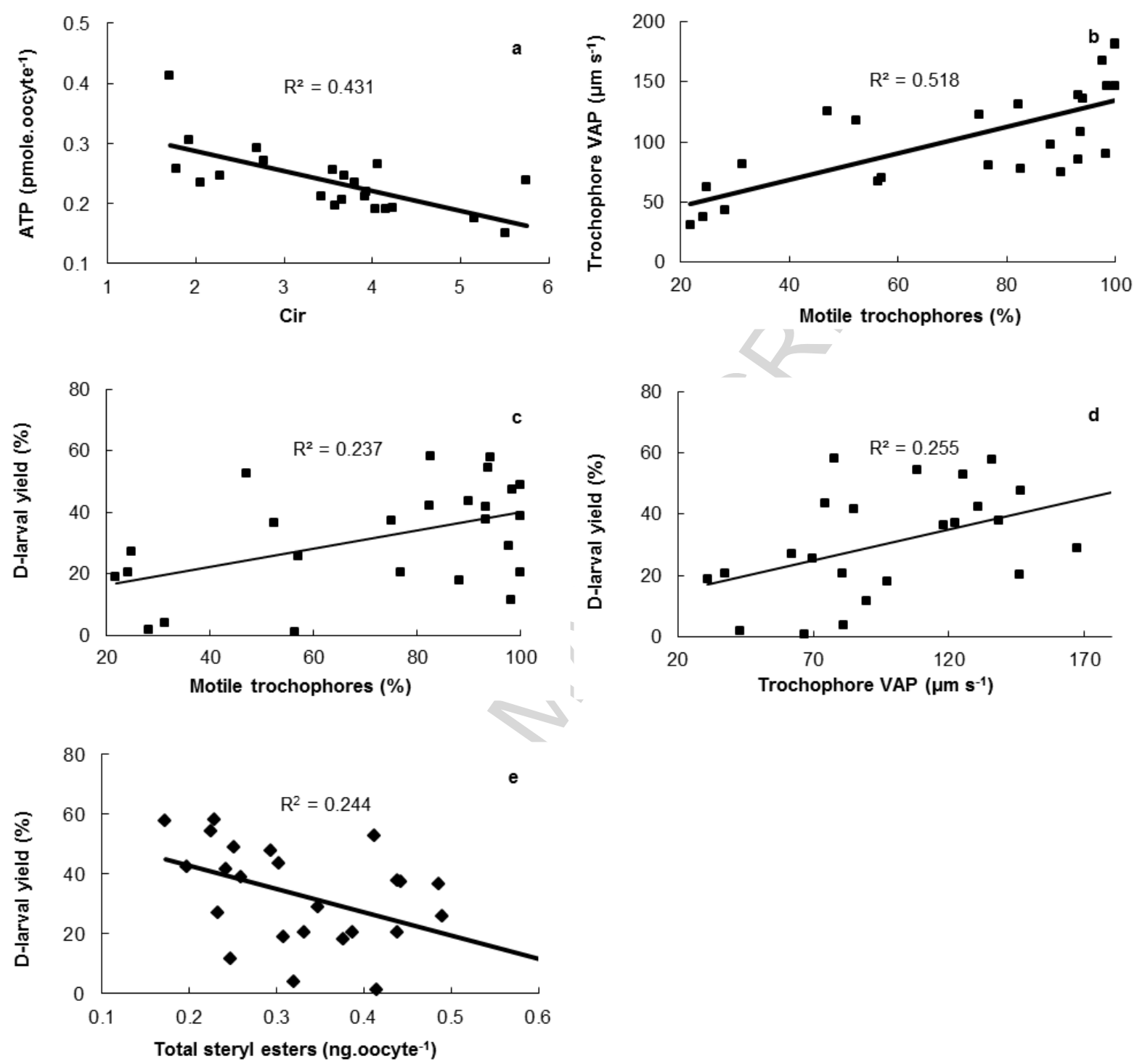

Figure 2 


\section{Table 1}

Sense and anti-sense sequences of primer pairs for real-time PCR analysis, used to amplify cDNA of 10 mRNA from each collected oocyte sample. PCR efficiencies were determined for each primer pair by determining the slopes of standard curves obtained from serial dilution analysis of the cDNA reference. GenBank accession numbers are indicated.

\begin{tabular}{|c|c|c|c|c|c|}
\hline GenBank \# & EST / mRNA name & Forward primer & Reverse primer & $\begin{array}{l}\text { Efficiency } \\
(\%)\end{array}$ & Reference \\
\hline EW779000 & $\begin{array}{l}\text { Pcna (Proliferating } \\
\text { Cell Nuclear Antigen) }\end{array}$ & 5'-GCTGCTCGATTTAGACTGTGA-3' & 5'-CTTGACTCCTTCCTTTGTACA-3' & 100.2 & Franco et al. (2010) \\
\hline CU988487 & $\begin{array}{l}\text { Prohibitin (regulator of } \\
\text { cell proliferation) }\end{array}$ & 5'-TGATGGTGGTCATCGGTCTA-3' & 5'-CTGAAACCATGGCACTCTGA-3' & 99.8 & Fleury et al (2009) \\
\hline CU993986 & $\begin{array}{l}\text { Cdc2 (protein kinase } \\
\text { Cell Division Cycle 2) }\end{array}$ & 5'-TGGTACAGAGCGCCAGAACT-3' & 5'-TGCCAGGAGCTCTCCAAATA-3' & 99.0 & Fleury et al (2009) \\
\hline AB242177 & Insulin-related peptide & 5'-AGAGAAAGCACTCGCCTTCA-3' & 5'-GCACTCGCAGACGATATTGA-3' & 99.4 & Hamano et al (2005) \\
\hline AM868819 & Insulin receptor b & 5'-GATGGCGGTGGAACATAAAT-3' & 5'-TCATCCACAGCTGACAGAGC-3' & 98.7 & Fleury et al (2009) \\
\hline AJ535669 & $\begin{array}{l}\text { Insulin relative } \\
\text { receptor }\end{array}$ & 5'-GAAGCACAGCATTCGTA-3' & 5'-TTGTGGACGAGAATACA-3' & 99.2 & Gricourt et al (2003) \\
\hline CX069172 & $\begin{array}{l}\text { Vitellogenin } 2(\mathrm{Cg}- \\
\text { Vtg2) }\end{array}$ & 5'-AGTCTACCCCCGTCCGTAT-3 & 5'-GTTCTGTGACGGAAAGTGA-3 & 100.0 & Llera et al (2012) \\
\hline FP009463 & $\begin{array}{c}\text { Camk4 } \\
\text { (Calcium/calmodulin- } \\
\text { dependent protein } \\
\text { kinase IV) }\end{array}$ & 5'-ATGTTGGTGGCAGTGCAG-3' & 5'-TGGAGAGACCGAAGTCAGC-3' & 99.2 & Fleury et al (2009) \\
\hline AY423380 & Vasa (RNA helicase) & 5'-CCGAGGAGATTCAGA-3' & 5'- ACGTCAGTGCAAGCACCA -3' & 100 & Fabioux et al (2004) \\
\hline
\end{tabular}




\section{Table 2}

Mean values of physical and biochemical parameters of

Pacific oyster oocytes and larvae.

\begin{tabular}{|c|c|}
\hline Parameter & Mean \pm SEM \\
\hline Gonad $\mathrm{pH}$ & $6.25 \pm 0.04$ \\
\hline Oocyte maximal diameter $(\mu \mathrm{m})$ & $74.6 \pm 1.3$ \\
\hline Oocyte circularity & $0.81 \pm 0.01$ \\
\hline Oocyte ATP content (pmol.oocyte ${ }^{-1}$ ) & $0.24 \pm 0.01$ \\
\hline Oocyte protein content (ng.oocyte ${ }^{-1}$ ) & $14.85 \pm 0.66$ \\
\hline Oocyte total lipid content (ng.oocyte ${ }^{-1}$ ) & $8.70 \pm 0.75$ \\
\hline \multicolumn{2}{|l|}{ Oocyte neutral lipid content (ng.oocyte ${ }^{-1}$ ) } \\
\hline Free sterol & $0.18 \pm 0.01$ \\
\hline Free fatty acid & $0.05 \pm 0.00$ \\
\hline Triglyceride & $4.49 \pm 0.18$ \\
\hline Ether of glycerol & $0.21 \pm 0.02$ \\
\hline Total steryl ester & $0.34 \pm 0.02$ \\
\hline Total neutral lipid & $5.27 \pm 0.21$ \\
\hline \multicolumn{2}{|l|}{ Oocyte mRNA level } \\
\hline Prohibitin & $1.61 \pm 0.09$ \\
\hline Insulin related peptide & $0.14 \pm 0.05$ \\
\hline Insulin receptor $b$ & $10.16 \pm 0.90$ \\
\hline Insulin relative & $3.61 \pm 0.23$ \\
\hline Vasa & $59.00 \pm 3.21$ \\
\hline Camk4 & $1.65 \pm 0.09$ \\
\hline Pcna & $3.60 \pm 0.15$ \\
\hline Vitellogenin 1 & $0.009 \pm 0.002$ \\
\hline Vitellogenin 2 & $0.013 \pm 0.003$ \\
\hline $\mathrm{Cdc} 2$ & $4.26 \pm 0.40$ \\
\hline Trochophore motility (\%) & $72.2 \pm 5.8$ \\
\hline Trochophore VAP $\left(\mu \mathrm{m} . \mathrm{s}^{-1}\right)$ & $104.0 \pm 8.8$ \\
\hline D-larval yield $(\%)$ & $31.8 \pm 3.5$ \\
\hline D-larval maximal diameter $(\mu \mathrm{m})$ & $78.5 \pm 0.3$ \\
\hline D-larval circularity & $0.86 \pm 0.00$ \\
\hline
\end{tabular}

